\title{
A new genus and species of the family Microdispidae (Acari: Prostigmata) associated with Oryctes nasicornis (Coleoptera: Scarabaeidae) and redescription of the monotypic genus Vietodispus Mahunka, 1975
}

\author{
Hamidreza Hajiqanbar ${ }^{*}$ and Farahnaz Hosseininaveh
}

\begin{abstract}
Background: Mites of the family Microdispidae (Acari: Prostigmata: Heterostigmata) are fungivorous, usually living in soil, litter, decaying plant materials, and similar substrates, and adult females have phoretic associations with arthropods, particularly insects. The family Microdispidae is poorly studied, and because of the vague descriptions of most of the genera and species, the taxonomy of this family is in a state of confusion. Previous to this study, more than 109 microdispid species in 17 genera have been described worldwide.

Results: In this study, a new genus, Neomicrodispus gen. nov. (Acari: Microdispidae) (type species Neomicrodispus iranicus sp. nov.) is described and illustrated based on phoretic females recovered from Oryctes nasicornis (Coleoptera: Scarabaeidae), which were collected from the forests in northern Iran. Also, the monotypic genus Vietodispus Mahunka, 1975 (type species Vietodispus calcaratus) is redescribed based on its holotype lent from the Hungarian Natural History Museum. The representatives of the family Microdispidae associated with arthropods are reviewed.

Conclusions: There are now 18 genera of this family worldwide that are primarily defined by reductions in their morphology. Because of poor description of some genera and species, synonymies or decreasing in systematic ranks may be expected. A review of arthropod associations, provided in this paper, showed that these mites are primarily associated with ants and beetles, where a rich source of various kinds of fungi particles is easily obtained.
\end{abstract}

Keywords: Heterostigmata; Mite; Neomicrodispus gen. nov.; Beetle; Phoretic relationship; Iran

\section{Background}

The cohort Heterostigmata, one of the two cohorts placed in the supercohort Eleutherengonides (Acari: Prostigmata) (Walter et al. 2009), mostly includes small mites associated with various arthropods. They are fungivores, parasites, parasitoids, and sometimes phytophages. Heterostigmata includes eight superfamilies and more than 2,000 described species. Based on Khaustov (2008), the family Microdispidae (Acari: Heterostigmata) is a member of the superfamily Pygmephoroidea. These mites inhabit soil, litter, decaying plant materials, and

\footnotetext{
* Correspondence: hajiqanbar@modares.ac.ir

Department of Entomology, Faculty of Agriculture, Tarbiat Modares University, 14115-336 Tehran, Iran
}

\section{Springer}

similar substrates, and adult females have phoretic associations with arthropods (Rack 1979; Kaliszewski et al. 1995; Khaustov 2006, 2009a; Walter et al. 2009; Hajiqanbar et al. 2012). About 109 species of 17 microdispid genera have been described; however, the taxonomy of this family is highly problematic and perplexed by vague generic and species descriptions, particularly over the last decades of the twentieth century. Here, we describe the 18th genus of this family that is associated with scarab beetles (Coleoptera: Scarabaeidae), collected from forests of Golestan Province, northern Iran, and redescribe the monotypic genus Vietodispus Mahunka, 1975 because of its similarity to the new genus and incomplete original description. In addition, the representatives of the 
family Microdispidae associated with arthropods are reviewed.

\section{Methods \\ Materials}

Mites were collected from scarabaeid beetles (Coleoptera: Scarabaeidae), which were captured directly in their habitat by forceps. The mite specimens were cleared in lactophenol and mounted in Hoyer's medium. The morphology of the specimens was studied with a phase contrast microscope (Olympus BX51, Olympus Corporation, Tokyo, Japan). All measurements in this description are given in micrometers for the holotype and three paratypes (in parentheses). The terminology and setal notation follow Lindquist (1986). The holotype of the new species is deposited in the Acarological Collection, Department of Entomology, Faculty of Agriculture, Tarbiat Modares University, Tehran, Iran. One paratype is deposited in the US National Museum of Natural History, Washington, D.C., USA. Other paratypes as well as the beetle host are retained with the holotype. The holotype of Vietodispus calcaratus was lent from the Hungarian Natural History Museum (HNHM).

\section{Systematics}

Family: Microdispidae Cross, 1965

Genus: Neomicrodispus Hajiqanbar and Hosseininaveh gen. nov.

\section{Type of species: Neomicrodispus iranicus Hajiqanbar and Hosseininaveh sp. nov.}

Diagnosis Gnathosomal capsule about two times longer than wide, dorsally with one pair of cheliceral setae $\left(c h_{1}\right)$ and ventrally with one pair of subcapitular setae $(s u)$; pharyngeal pump system includes three pumps, second pharyngeal pump large, transversely striated, pharyngeal pumps 1 and 3 reduced; stigmata elongated with a distinct tracheal system; cupuli ia and ih rounded; setal formula of coxal fields: 2-2-3-2 (setae $4 a$ absent); posterior margin of poststernal plate entire; with three pairs of pseudanal setae $\left(p s_{1}, p s_{2}\right.$, and $\left.p s_{3}\right)$; leg I with no ambulacrum; leg setal formula: leg I: $1-3-4-14(+1 \omega+2 \phi)$, leg II: $1-3-3-4(1 \phi)-6$ $(1 \omega)$, leg III: $1-2-2-4(1 \phi)-6$, leg IV: $1-2-1-3(1 \phi)-6$, tibial IV seta $v$ " absent.

Description of adult female The description of adult female is shown in Figures 1, 2, 3, 4, and 5.

Gnathosoma. Gnathosomal capsule about two times longer than wide, dorsally with one pair of cheliceral setae $\left(c h_{1}\right)$; ventrally with one pair of subcapitular setae (su). Palps short and compressed to gnathosomal capsule, with two pairs of setae, $d F e$ and $d G e$ and with small terminal claw.

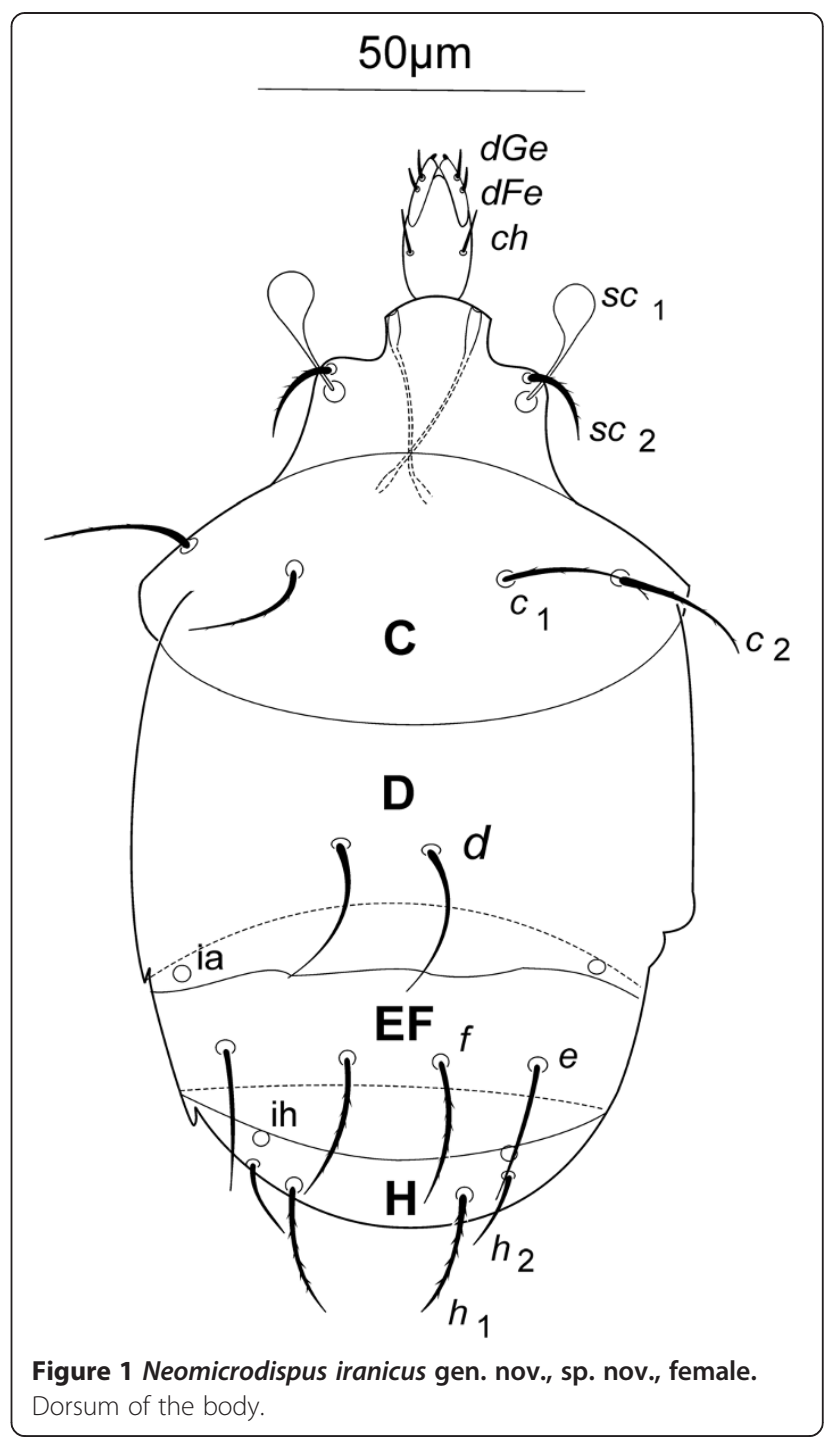

Pharynx. Pharyngeal pump system including three pumps, second pharyngeal pump large, transversely striated, pharyngeal pumps 1 and 3 reduced.

Dorsal idiosoma. Prodorsal shield with one pair of setae $\left(s c_{2}\right)$, one pair of capitate trichobothridia $\left(s c_{1}\right)$, and one pair of elongate stigmata with a distinct tracheal system. Hysterosoma with four visible tergites: tergite $\mathrm{C}$ with two pairs of setae $\left(c_{1}\right.$ and $\left.c_{2}\right)$; tergite $\mathrm{D}$ widest tergite, with one pair of setae $(d)$ and one pair of round cupuli; tergite EF with two pairs of setae $(e$ and $f)$; tergite $\mathrm{H}$ with two pairs of setae $\left(h_{1}\right.$ and $\left.h_{2}\right)$ and one pair of round cupuli.

Ventral idiosoma. Apodemes (ap1 to ap4, appr, apsej, appo) well-developed, ap5 absent. Setal formula of coxal fields: 2-2-3-2. Setae $4 a$ absent. Anterior genital sclerite (ags) subtriangular. Pseudanal plate with three pairs of setae $\left(p s_{1}, p s_{2}\right.$, and $\left.p s_{3}\right)$. 


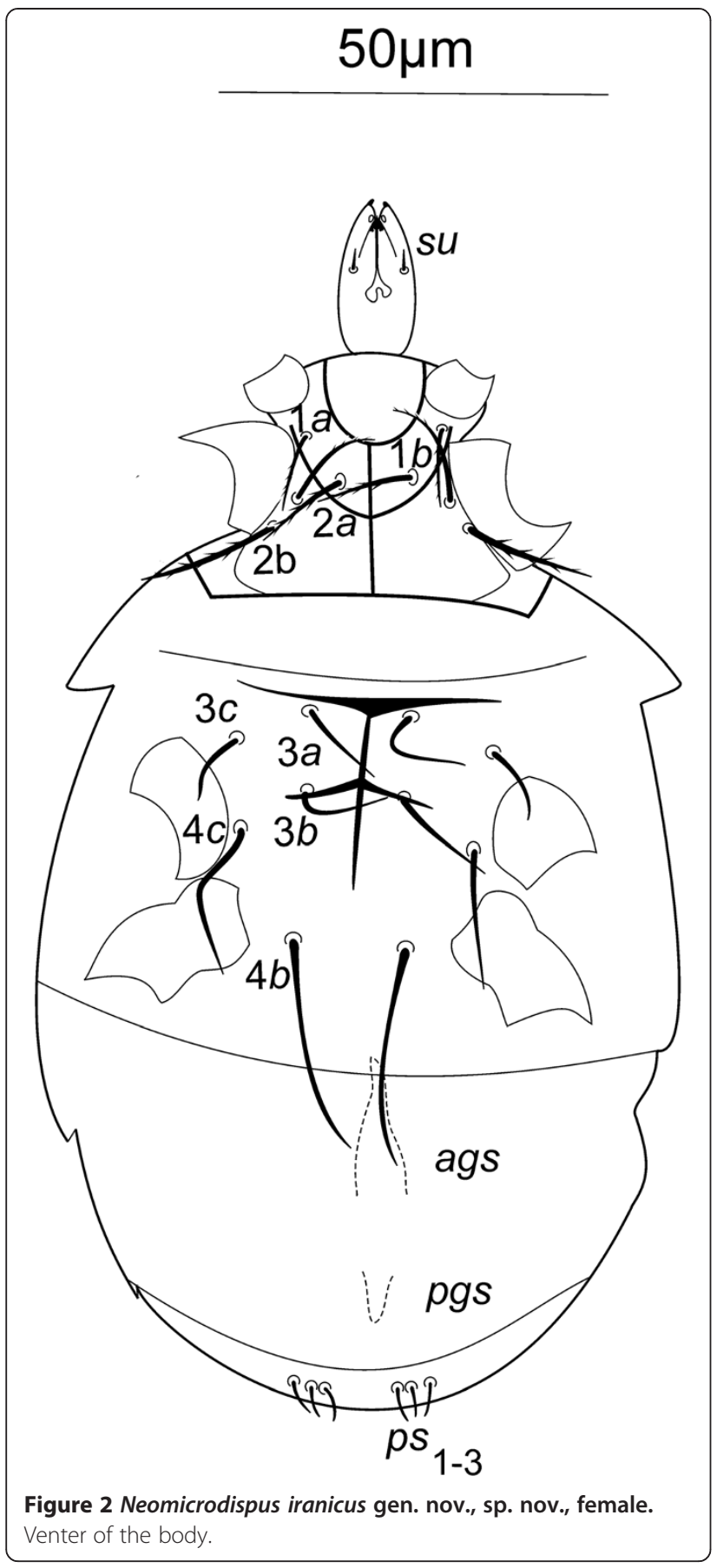

Legs. All legs five-segmented except leg I (four-segmented). Leg I: slightly thinner than other legs, with no ambulacrum, setal formula (with number of solenidia in parentheses): Tr $1 ; v^{\prime}-\mathrm{Fe} 3 ; v^{\prime \prime}, l^{\prime}, d$ - Ge $4 ; l^{\prime}, v^{\prime}, v^{\prime \prime}, l^{\prime \prime}$ -

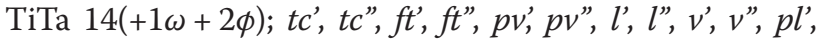
$p l ", d, k$. Leg II: with pair of claws and empodium, setal

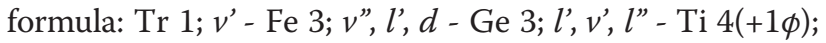
$l^{\prime}, v^{\prime}, v^{\prime \prime}, d$ - Ta $6(+1 \omega) ; t c^{\prime}, t c^{\prime \prime}, p v^{\prime}, p v^{\prime \prime}, p l^{\prime \prime}, u^{\prime}$. Leg III: with pair of claws and empodium, setal formula: $\operatorname{Tr} 1 ; v^{\prime}$ - Fe 2;

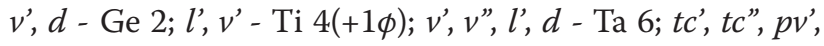

$p v^{\prime \prime}, p l$, $u$ '. Leg IV: with pair of claws and empodium, setal formula: $\operatorname{Tr} 1 ; v^{\prime}-\mathrm{Fe} 2 ; v^{\prime}, d$ - Ge $1 ; v^{\prime}-\mathrm{Ti} 3(+1 \phi) ; v^{\prime}, l^{\prime}, d$ Ta 6; $t c^{\prime}, t c^{\prime \prime}, p v^{\prime}, p v^{\prime \prime}, p l^{\prime \prime}, u^{\prime}$.

Male and larva. Unknown.

Differential diagnosis The new genus is most similar to the genera Microdispus Paoli, 1911, Punicodoxa Mahunka, 1978, and Paramicrodispus Khaustov, 2009 because of the following characters: stigmata elongate, cupuli rounded, and tibiotarsus I with three solenidia. The Neomicrodispus gen. nov. differs from Microdispus by the absence of setae $4 a$ (present in Microdispus) and 14 setae on tibiotarsus I (13 setae in Microdispus, $p v$ " absent). The new genus differs from Punicodoxa by the absence of setae $4 a$ (present in Punicodoxa) and three pairs of pseudoanal setae (two pairs in Punicodoxa). The Neomicrodispus gen. nov. differs from Paramicrodispus by the absence of setae $4 a$ (present in Paramicrodispus) and three pairs of pseudoanal setae (two pairs in Paramicrodispus, $p s_{2}$ vestigial). The new genus could also be similar to Vietodispus Mahunka, 1975, due to absence of setae $4 a$, cupuli rounded, three pairs of pseudoanal setae, and tibiotarsus I with three solenidia. Neomicrodispus gen. nov. differs from Vietodispus by its elongate stigmata (stigmata small and rounded in Vietodispus), entire posterior margin of the poststernal plate (posterior margin of poststernal plate tripartite in Vietodispus), and 14 setae on tibiotarsus I (15 setae in Vietodispus). The new genus also differs from all mentioned genera by the absence of setae $v$ " on tibia IV. The key characters of six microdispid genera are summarized in Table 1.

Etymology The generic name is derived from 'Neo' (Greek, neos which means new) and 'microdispus' (the root name of Microdispidae).

\section{Neomicrodispus iranicus Hajiqanbar and Hosseininaveh} sp. nov.

Description of adult female The description of adult female is shown in Figures 1, 2, 3, 4, and 5.

Gnathosoma (Figure 3a,b). Length of gnathosoma 20 (16 to 24), width 13 (10 to 15). Cheliceral setae $c h_{1} 7$ (7 to 8). Subcapitular setae $s u 2$ (2 to 3). Palp setae $d F e ~ 3$ (3 to 4) and $d G e 4$ (4 to 5), all gnathosomal setae smooth.

Idiosomal dorsum (Figure 1). Idiosomal length 165 (150 to 165), maximum width 99 (82 to 100). All tergites smooth. All dorsal setae pointed. Setae $s c_{2}$ barbed, setae $c_{1}$ and $c_{2}$ indistinctly barbed and subequal, setae $d$ smooth, setae $f$ barbed, setae $e$ smooth, setae $f$ longer than setae $e$, setae $h_{1}$ barbed, setae $h_{2}$ smooth, setae $h_{1}$ distinctly longer than $h_{2}$. Length of dorsal setae: $s c_{2} 15$ (13 to 16), $c_{1} 23$ (21 to 23 ), $c_{2} 24$ (23 to 26), $d 30$ (27 to 30), e 25 (21 to 25), $f$ 32 (28 to 32 ), $h_{1} 23$ (22 to 24 ), $h_{2} 15$ (14 to 16). Distances between dorsal setae: $s c_{2}-s c_{2} 32$ (31 to 32 ), $c_{1}-c_{1} 37$ (36 to 


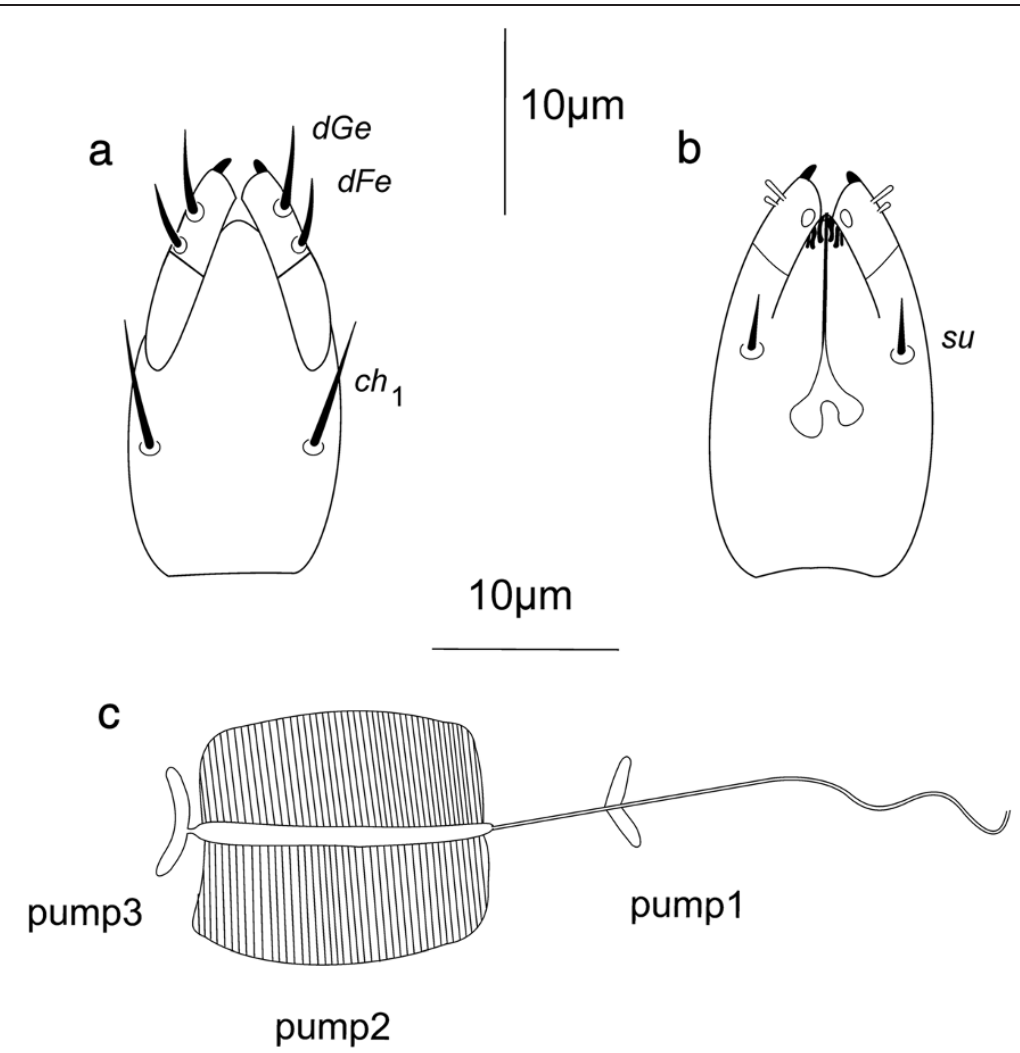

Figure 3 Neomicrodispus iranicus gen. nov., sp. nov., female. (a) Gnathosoma, dorsal view. (b) Gnathosoma, ventral view. (c) Pharyngeal pumps.

38), $c_{1}-c_{2} 19$ (17 to 19$), d-d 15$ (14 to 17$), e-f 18$ (16 to 18$)$, $f-f 21$ (18 to 22 ), $h_{1}-h_{1} 26$ (25 to 28$), h_{1}-h_{2} 8$ (8 to 10 ).

Idiosomal venter (Figure 2). All ventral plates smooth. Apodemes 1 and 2 reaching to presternal apodeme (appr), appr reaching to sejugal apodeme (apsej), apodemes 3 extending beyond setae $3 a$ and apodemes 4 reaching to setae $3 b$. Anterior border of poststernal plate faintly concave and posterior border of poststernal plate entire. Setae $1 b$ and $2 b$ with several large barbs, setae $2 a$ and $1 a$ indistinctly barbed, other ventral setae smooth, seta $1 b$ longer than $1 a$, seta $2 b$ the longest on anterior sternal plate, $3 a$ and $3 b$ subequal, $3 c$ shorter than them, setae $4 a$ absent, setae $4 b$ the longest on posterior sternal plate. Anterior genital sclerite (ags) rhombus. Setae $p s_{1}, p s_{2}$, and $p s_{3}$ subequal. Length of ventral setae: $1 a 10$ (10 to 12), $1 b 18$ (15 to 18 (, $2 a 21$ (18 to 22 ), $2 b 24$ (24 to 25 ), $3 a 19$ (19 to 22 ), $3 b 21$ (21 to 23 ), $3 c 14$ (13 to 15 ), $4 b 41$ (39 to 42 ), $4 c 29$ (25 to 29 ), $p s_{1} 6$ (5 to 7 ), $p s_{2} 5$ (4 to 6 ), $p s_{3} 5$ (5 to 7 ).

Legs (Figures 4 and 5). Leg I (Figure 4a): tibiotarsus: with four eupathidial setae $t c^{\prime}, t c^{\prime}, f t^{\prime}$, and $f t^{\prime \prime}$, setae $t c^{\prime}$ and $t c$ " subequal and longer than other eupathidial setae, setae $p v^{\prime}, v^{\prime}, l^{\prime}, l$ ", and $p l^{\prime \prime}$ barbed, the rest of the setae of the segment smooth, solenidia $\omega_{1} 7$ (7 to 8$)>\phi_{1} 6$ (5 to 6) $>\phi_{2} 4$ (3 to 4), solenidion $\omega_{1}$ baculiform, longer than other solenidia, solenidion $\phi_{1}$ clubbed, solenidion $\phi_{2}$ baculiform, thinner than $\omega_{1}$. Genu: seta $l^{\prime}$ smooth, $v^{\prime}, v^{\prime \prime}, l$ " barbed, $v$ " the shortest setae of the segment, $l$ " and $v^{\prime}$ subequal and shorter than l'. Femur: setae $v$ ", $d$, and $l^{\prime}$ subequal. Trochanter: seta $v^{\prime}$ the shortest setae of the leg.

Leg II (Figure 4b). Tarsus: setae $t c$ " and $u$ ' smooth, other setae of the segment barbed, solenidion $\omega 6$ (6 to 7 ) finger-shaped. Tibia: all setae barbed except $d$, setae $l$ ', $v$ ", and $v^{\prime}$ subequal and longer than $d$, solenidion $\phi 3$ (2 to 3) finger-shaped. Genu: setae $v^{\prime}$ and $l$ " barbed, longer than seta $l$ '. Femur: all setae smooth, $d$ distinctly longer than other setae, $l$ ' the shortest setae of the leg. Trochanter: seta $v$ 'subequal to $v$ ' of genu.

Leg III (Figure 5a). Tarsus: setae $t c^{\prime}$ and $t c$ " subequal and longer than other setae of the segment, setae $p v$ ' barbed. Tibia: setae $d$ and $v^{\prime}$ subequal and longer than other setae of the segment, setae $l$ ' and $v$ ' barbed, solenidion $\phi 3$ (3 to 4) small. Genu: setae v' and l'subequal, setae $v$ ' barbed. Femur: seta $d$ barbed and distinctly longer than $v^{\prime}$. Trochanter: seta $v^{\prime}$ smooth.

Leg IV (Figure 5b). Longer than other legs. Tarsus: all setae barbed except $u^{\prime}$ and $p l$ ', $u$ ' the shortest and $t c$ " the longest seta of the segment. Tibia: all setae barbed except $l, v^{\prime}$ and $l^{\prime}$ subequal and shorter than setae $d$, solenidion $\phi 2$ (1 to 2 ) tiny. Genu: seta $v^{\prime}$ barbed. Femur: seta $d$ barbed and more than two times longer than $v^{\prime}$. Trochanter: seta $v$ 'subequal to femoral seta $v$ '. 


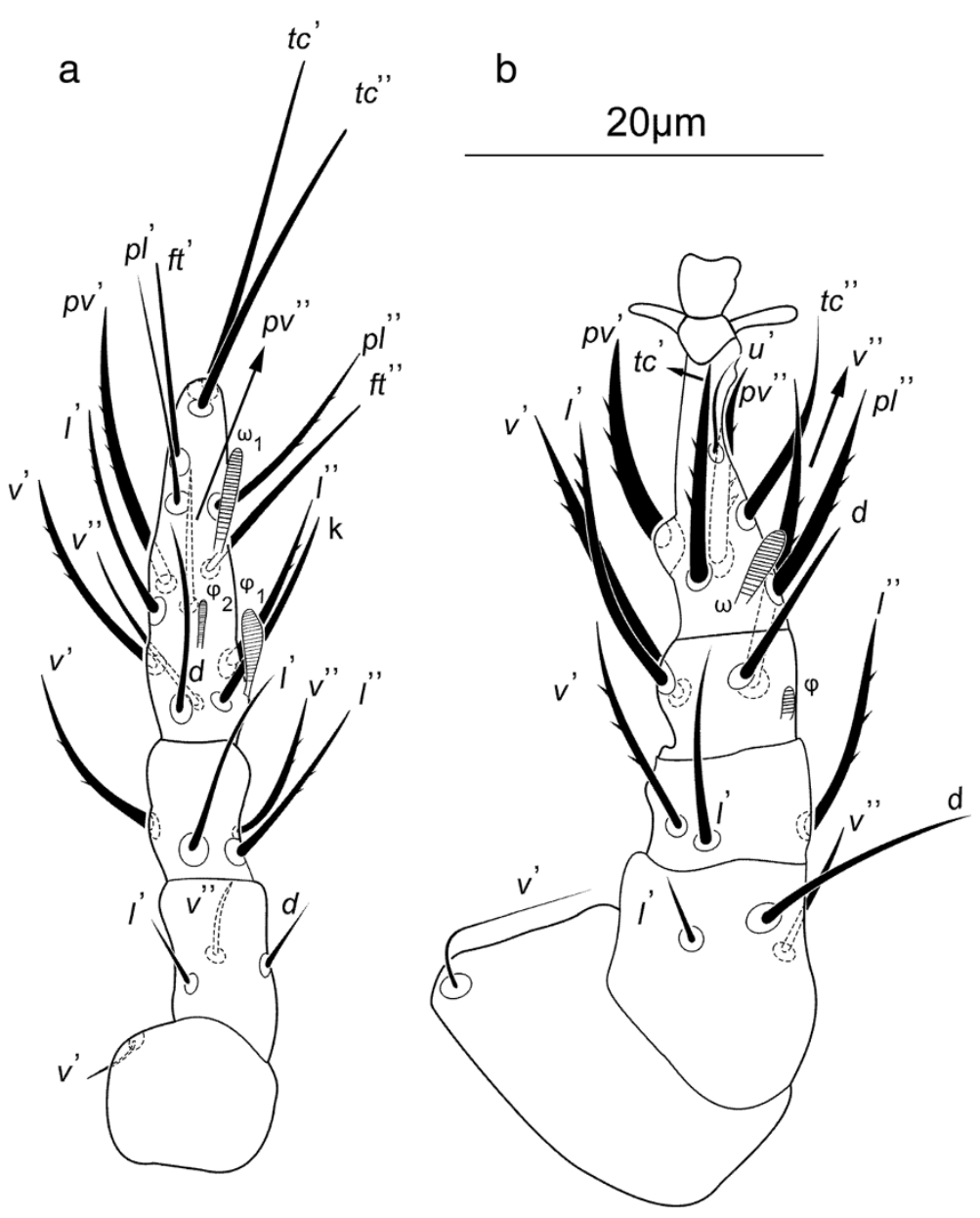

Figure 4 Neomicrodispus iranicus gen. nov., sp. nov., female. (a) Leg I. (b) Leg II.

Etymology The name of the new species refers to its country of origin, Iran.

Type of material Holotype phoretic female (VR20100715) and three paratypes found in a vial containing the beetle Oryctes nasicornis (Coleoptera: Scarabaeidae) and ethyl alcohol 75\%. The host beetle was collected in Naharkhoran forest, Golestan Province, northern Iran, $36.46^{\circ} \mathrm{N}, 54.27^{\circ} \mathrm{E}$, altitude 450 m., coll. V. Rahiminejad, 15 July 2010.

\section{Genus Vietodispus Mahunka, 1975}

Diagnosis Gnathosomal capsule about three times longer than its width, dorsal and ventral sides each with only one pair of setae; first pharyngeal pump reduced, second pump enlarged, third pump rounded; stigmata small and rounded; cupuli $i a$ and $i$ rounded; setal formula of coxal fields: 2-2-3-2 (setae $4 a$ absent); posterior margin of poststernal plate tripartite; three pairs of pseudanal setae $\left(p s_{1}, p s_{2}\right.$, and $\left.p s_{3}\right)$; leg I with no ambulacrum; leg setal formula: leg I: 1-3-4-15(3), leg II: 1-3-3-4(1)-6(1), leg III: 1-2-2-4(1)-6, leg IV: 1-2-1-4(1)-6.
Redescription of adult female Gnathosoma. Gnathosomal capsule about three times longer than its width, dorsally with only one pair of cheliceral setae (ch), ventrally with one pair of subcapitular setae $(s u)$. Palps short and compressed to gnathosomal capsule, with two pairs of setae, $d F e$ and $d G e$.

Pharynx. Pharyngeal system including three pumps, weakly sclerotized, first pharyngeal pump reduced, second pump enlarged, third pump rounded.

Dorsal idiosoma. Prodorsal shield with one pair of setae $s c_{2}$, one pair of capitate trichobothridia $\left(s c_{1}\right)$, and one pair of small and round stigmata. Hysterosoma with four visible tergites: tergite $C$ with two pairs of setae $\left(c_{1}\right.$ and $c_{2}$ ), tergite $\mathrm{D}$ widest on hysterosoma with one pair of setae $(d)$ and one pair of rounded cupuli (ia), tergite EF with two pairs of setae ( $e$ and $f$ ), tergite $\mathrm{H}$ with two pairs of setae $\left(h_{1}\right.$ and $\left.h_{2}\right)$ and one pair of rounded cupuli $(i h)$.

Ventral idiosoma. Apodemes well-developed, ap5 present. Setal formula of coxal fields: 2-2-3-2. Setae $4 a$ absent. Anterior genital sclerite (ags) subtriangular. Pseudanal plate with three pairs of setae $\left(p s_{1}, p s_{2}\right.$, and $\left.p s_{3}\right)$. 

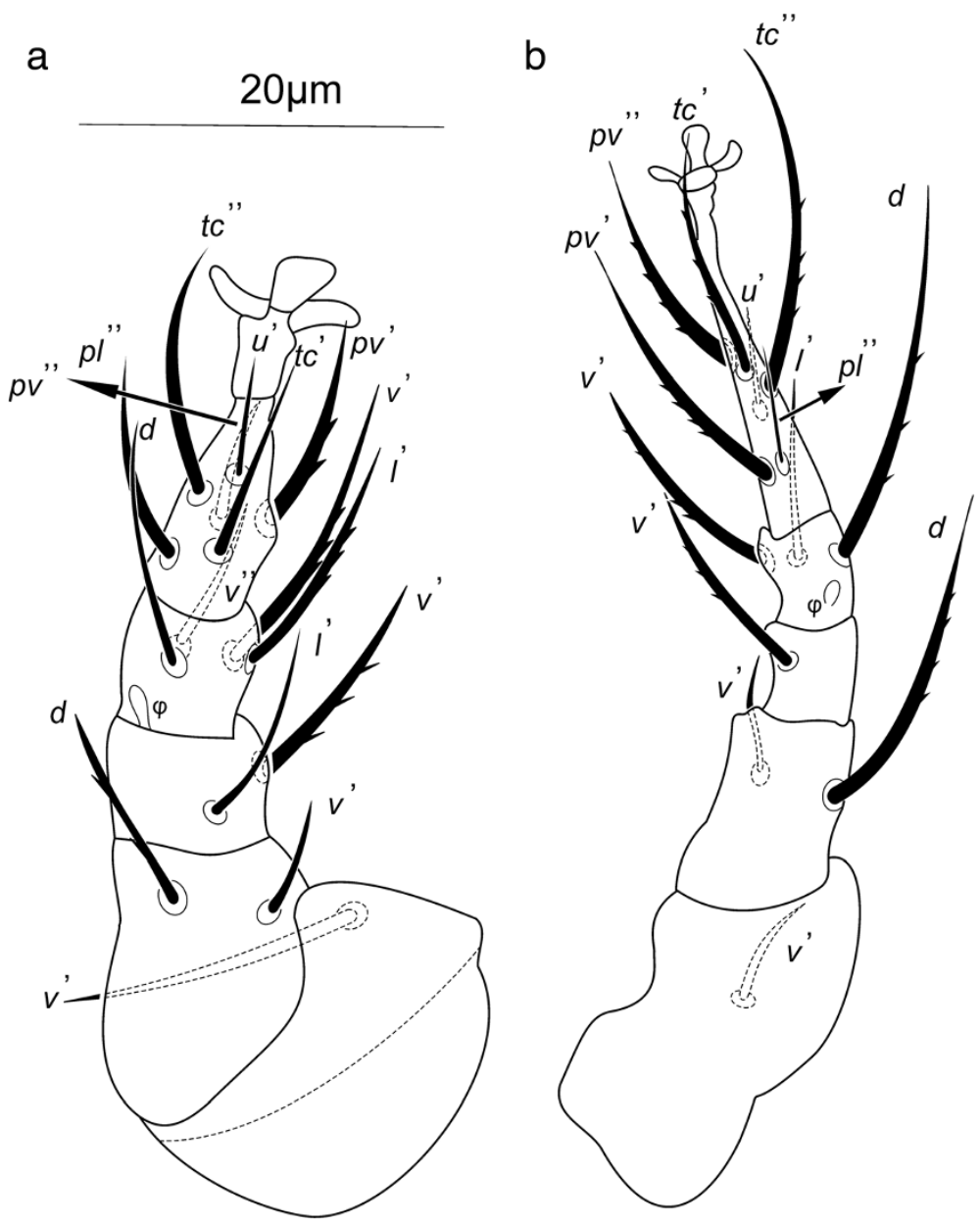

Figure 5 Neomicrodispus iranicus gen. nov., sp. nov., female. (a) Leg III. (b) Leg IV.

Legs. All legs five-segmented except leg I (four-segmented). Leg I: with no ambulacrum, setal formula: $\mathrm{Tr}$ $1 ; v^{\prime}-$ Fe $3 ; v^{\prime \prime}, l^{\prime}, d$ - Ge 4; $l^{\prime}, v^{\prime}, v^{\prime \prime}, l^{\prime \prime}-$ TiTa $15(+2 \omega+$ $1 \phi) ; p^{\prime \prime}, t c^{\prime}, t c^{\prime \prime}, f t^{\prime}, f t^{\prime \prime}, p v^{\prime}, p v^{\prime \prime}, l^{\prime}, l^{\prime \prime}, v^{\prime}, v^{\prime \prime}, p l^{\prime}, p l^{\prime \prime}, d, k$. Leg II: with pair of claws and empodium, setal formula:

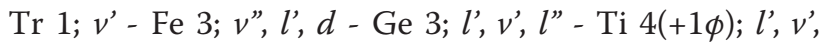
$v^{\prime \prime}, d$ - Ta $6(+1 \omega) ; t c^{\prime}, t c^{\prime \prime}, p v^{\prime}, p v^{\prime \prime}, p l^{\prime \prime}, u^{\prime}$. Leg III: with pair of claws and empodium, setal formula: Tr $1 ; v^{\prime}-\mathrm{Fe}$

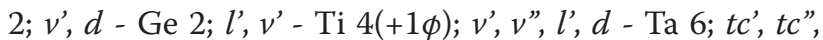
$p v^{\prime}, p v^{\prime \prime}, p l, u^{\prime}$. Leg IV: with pair of claws and

Table 1 Comparison of some characters of the Neomicrodispus gen. nov. with five genera

\begin{tabular}{|c|c|c|c|c|c|c|}
\hline & Microdispus & Paramicrodispus & Premicrodispus & Punicodoxa & Vietodispus & $\begin{array}{l}\text { Neomicrodispus } \\
\text { gen. nov. }\end{array}$ \\
\hline Setae $4 a$ & + & + & \pm & + & - & - \\
\hline Stigma & Elongate & Elongate & $\begin{array}{l}\text { Elongate (the length } 4 \\
\text { times longer than the width) }\end{array}$ & Elongate & Small and rounded & Elongate \\
\hline Cupuli & Rounded & Rounded & Rhombic & $?$ & Rounded & Rounded \\
\hline $\begin{array}{l}\text { Posterior margin of the } \\
\text { posterior sternal plate }\end{array}$ & Entire & Entire & Tripartite & Entire & Tripartite & Entire \\
\hline Ps setae & 3 pairs & $\begin{array}{l}3 \text { pairs ( } p s_{2} \\
\text { vestigial) }\end{array}$ & 2 pairs, rarely 3 pairs & 2 pairs & 3 pairs & 3 pairs \\
\hline Number of setae on tibiotarsus I & 13 & 14 & 15 & $?$ & 15 & 14 \\
\hline $\begin{array}{l}\text { Number of solenidia } \\
\text { on tibiotarsus I }\end{array}$ & 3 & 3 & 3 to 4 & 3 & 3 & 3 \\
\hline Number of setae on tibia IV & 4 & 4 & 4 & 4 & 4 & 3 \\
\hline
\end{tabular}


empodium, setal formula: $\operatorname{Tr} 1 ; v^{\prime}$ - Fe $2 ; v^{\prime}, d$ - Ge $1 ; v^{\prime}$ Ti 4(+1ф); $v^{\prime}, v^{\prime \prime}, l^{\prime}, d$ - Ta 6; $t c^{\prime}, t c^{\prime \prime}, p v^{\prime}, p v^{\prime \prime}, p l^{\prime \prime}, u^{\prime}$.

Male and larva. Unknown.

\section{Vietodispus calcaratus Mahunka, 1975}

Redescription of adult female The redescription of adult female is shown in Figures 6, 7, 8, 9, and 10.

Gnathosoma (Figure 8a,b). Cheliceral setae (ch) 12, subcapitular setae (su) 9. Palp setae $d F e 3$ and $d G e$ 4. All gnathosomal setae smooth.

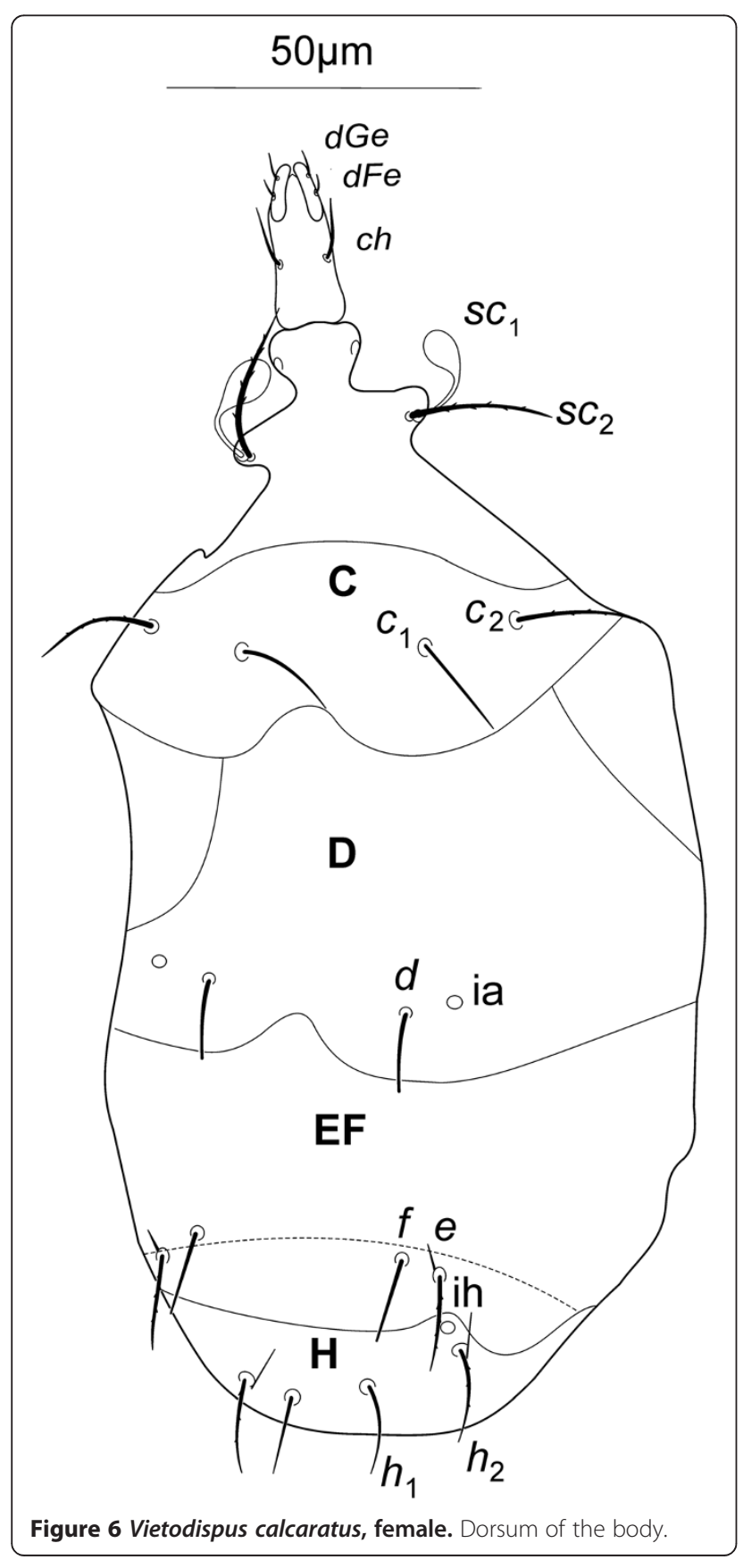

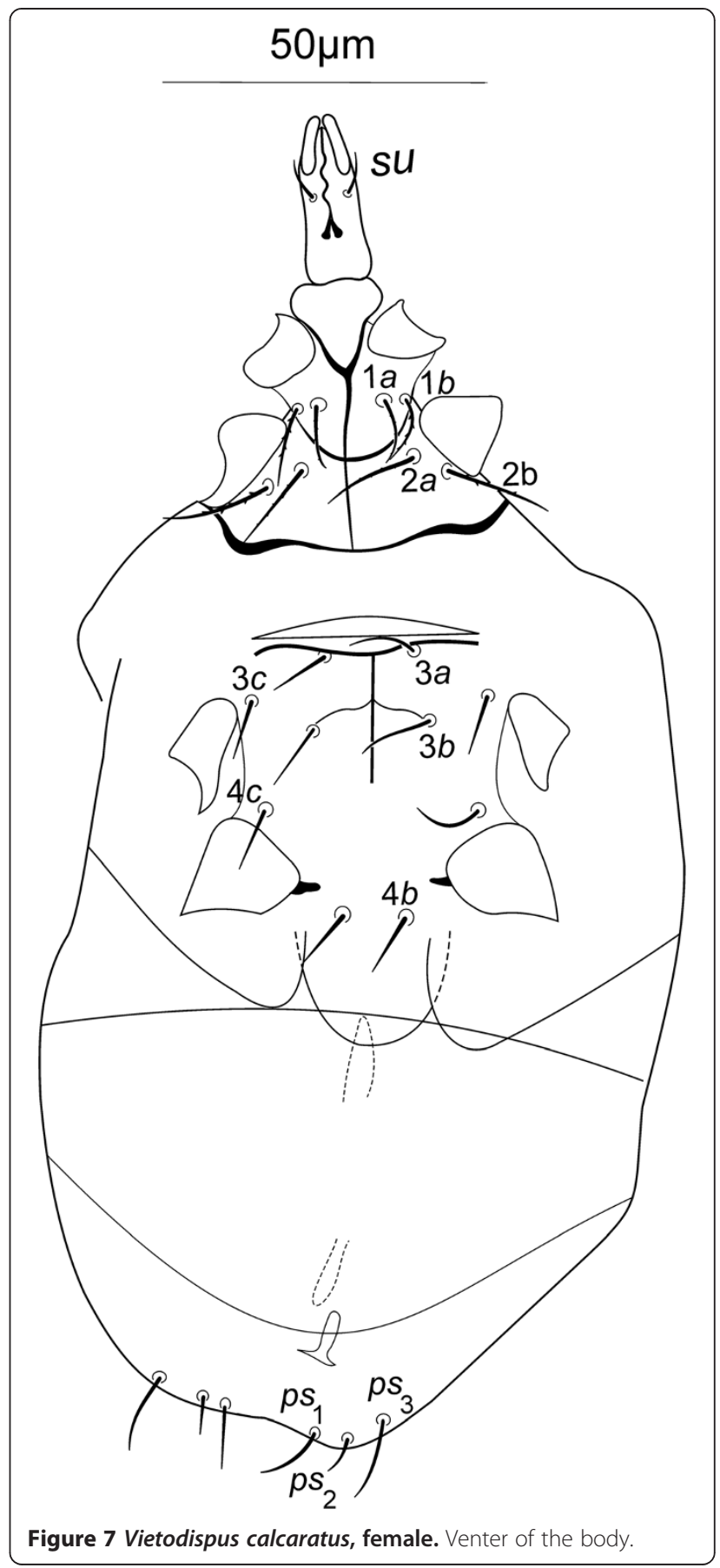

Idiosomal dorsum (Figure 6). Idiosomal length 192, width 97. All tergites smooth. Dorsal setae smooth or barbed, all dorsal setae pointed except setae $d$ which is blunt-ended, setae $s c_{2}$ distinctly barbed, setae $c_{2}$ barbed and longer than setae $c_{1}$, posterior border of tergite $C$ with excision, setae $d$ smooth, posterior border of tergite D with excision, setae $e$ barbed, setae $f$ smooth, setae $e$ longer than setae $f$, bases of setae $e$ associated with weakly developed apodemes directed anteromedially, 


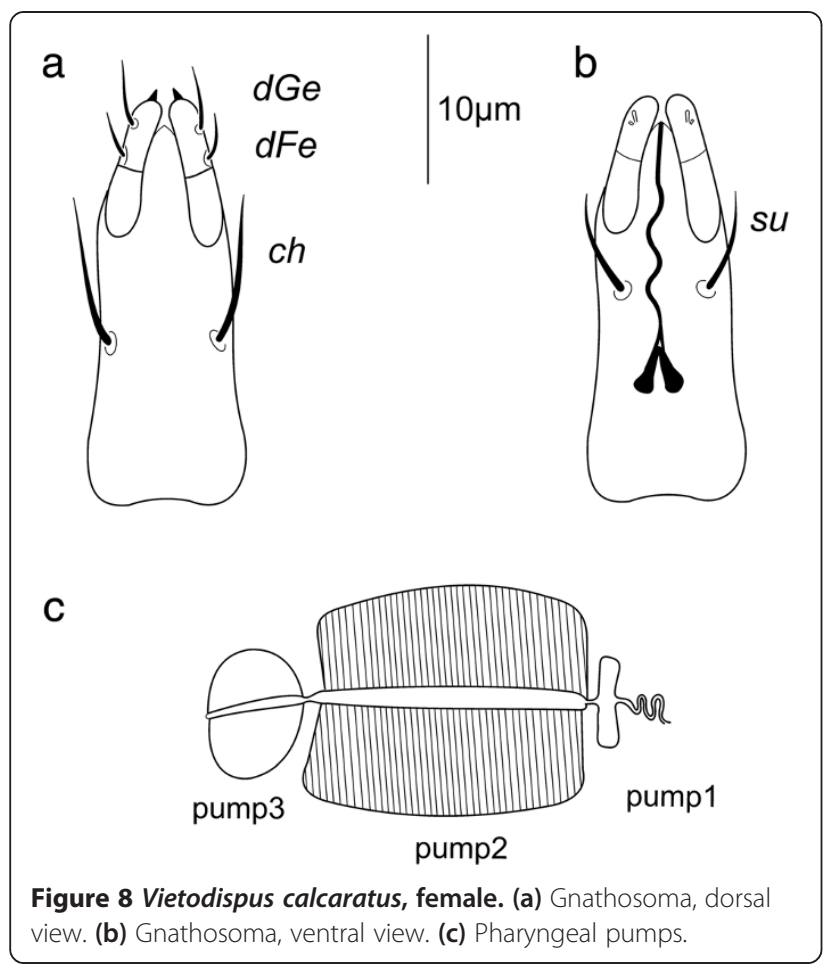

Figure 8 Vietodispus calcaratus, female. (a) Gnathosoma, dorsal view. (b) Gnathosoma, ventral view. (c) Pharyngeal pumps. posterior border of tergite EF with excision, setae $h_{2}$ barbed and associated to one thin apodemes, setae $h_{1}$ smooth, both subequal. Length of dorsal setae: $s c_{2} 22, c_{1}$ $15, c_{2} 21, d 14, e 17, f 15, h_{1} 16, h_{2} 17$. Distances between dorsal setae: $s c_{2}-s c_{2} 26, c_{1}-c_{1} 31, c_{2}-c_{2} 62, d-d$ 34, e-e 47, $e-f 7, f-f 35, h_{1}-h_{1} 14, h_{1}-h_{2} 17, h_{2}-h_{2} 37$.

Idiosomal venter (Figure 7). All ventral plates smooth. Apodemes 1 and 2 reaching to presternal apodeme, appr not reaching to sejugal apodeme, apodemes 3 extending beyond setae $3 a$, and apodemes 4 reaching to setae $3 b$, apodeme 5 short. Anterior border of poststernal plate faintly concave and posterior border of poststernal plate tripartite. Setae $1 a$ and $2 a$ indistinctly barbed, setae $1 b$ and $2 b$ with distinct barbs, other ventral setae smooth, seta $1 a$ and $1 b$ subequal, seta $2 a$ and $2 b$ subequal, seta $3 a$ and $3 b$ subequal, seta $3 c$ smaller than them, setae $4 a$ absent, setae $4 b$ and $4 c$ subequal. Anterior genital sclerite rhomboid. Setae $p s_{3}$ longer than $p s_{1}$, setae $p s_{1}$ longer than $p s_{2}$. Length of ventral setae: $1 a 11,1 b 10,2 a 17,2 b 16,3 a$ $12,3 b 13,3 c 10,4 b 12,4 c 11, p s_{1} 10, p s_{2} 6, p s_{3} 13$.

Legs (Figures 9 and 10). Leg I (Figure 9a): Tibiotarsus: with five eupathidial setae $p^{\prime \prime}, f t^{\prime}, f t^{\prime \prime}, t c^{\prime}, t c^{\prime \prime}$, setae $t c^{\prime}$ longer than $t c^{\prime \prime}$, setae $p v^{\prime \prime}$ longer than $p v^{\prime}$, setae $d$ and $k$ subequal, setae $v^{\prime}$ shorter than $v^{\prime \prime}$, setae $l$ "longer than $l$ ', setae $p l$, $l$ " and $v^{\prime \prime}$ barbed, solenidia $\omega_{1} 5$ and $\phi_{1} 5>\omega_{2} 2$, solenidion $\omega_{2}$ uniformly thin, solenidion $\omega_{1}$ finger-shaped, solenidion

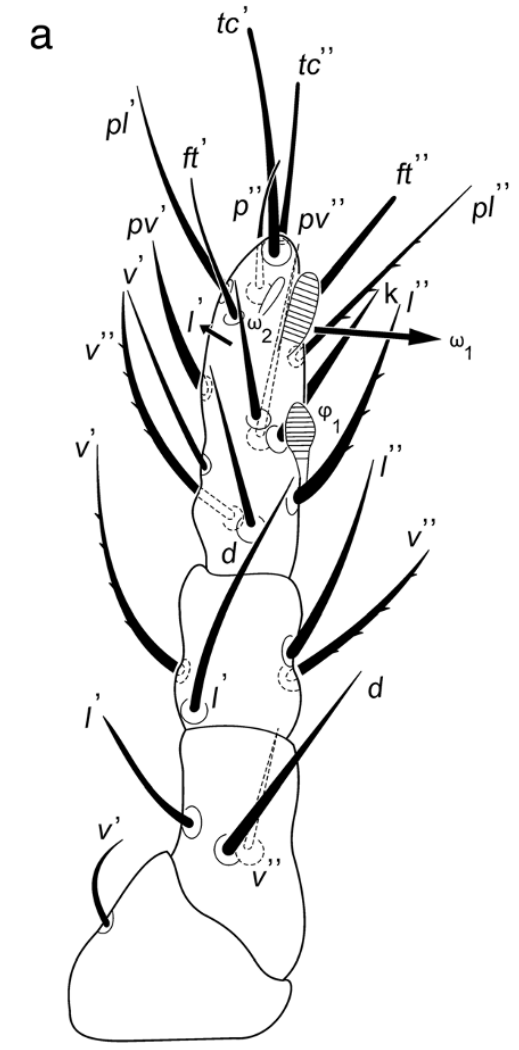

b $20 \mu \mathrm{m}$

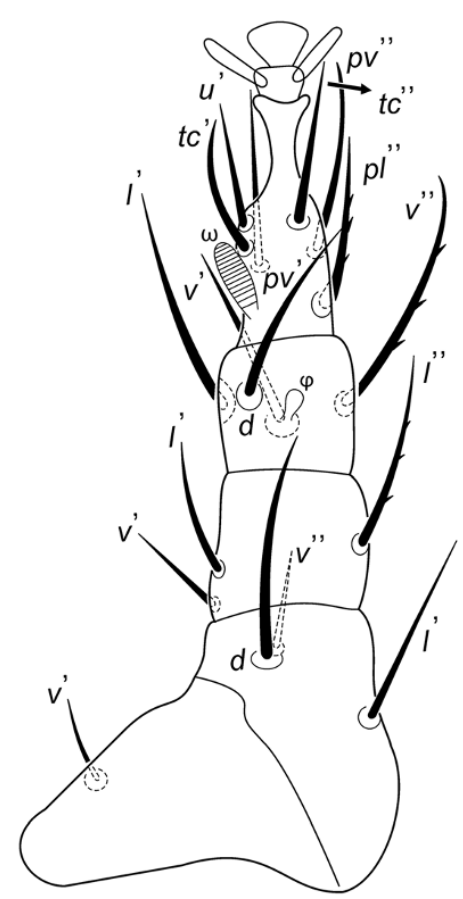

Figure 9 Vietodispus calcaratus, female. (a) Leg I. (b) Leg II. 


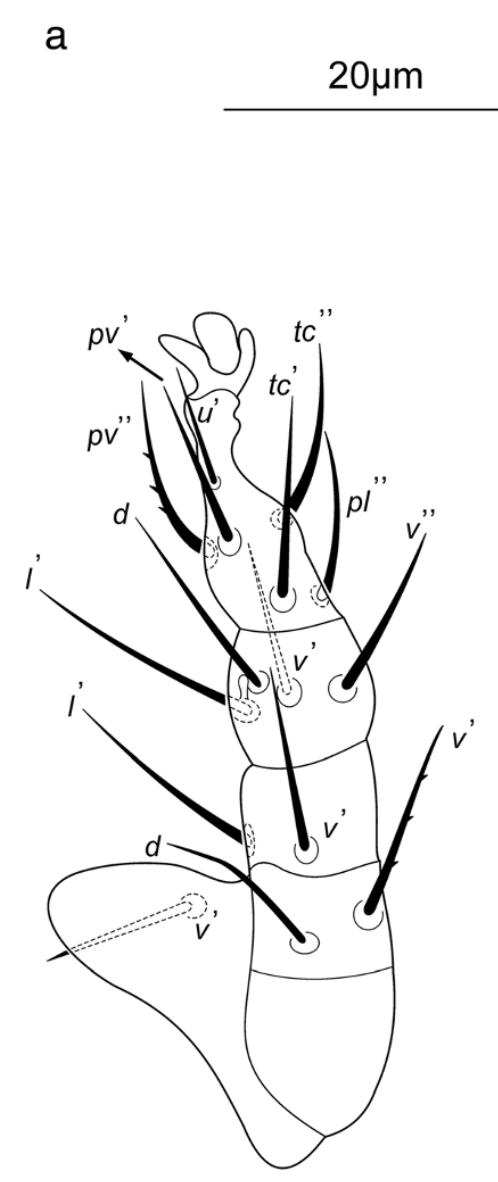

b

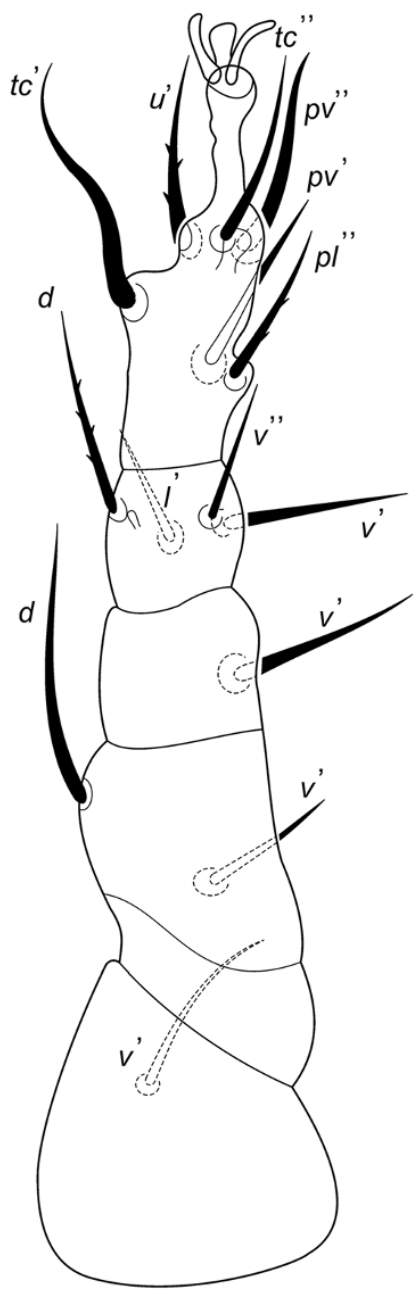

Figure 10 Vietodispus calcaratus, female. (a) Leg III. (b) Leg IV.

$\phi_{1}$ clubbed. Genu: with setae $l$ ' and $v^{\prime}$ subequal and longer than $l$ " and $v$ ", setae $v^{\prime}$ and $v^{\prime \prime}$ barbed. Femur: with setae $d$ longer than other setae of the segment. Trochanter: with seta $v^{\prime}$.

Leg II (Figure 9b). Tarsus: with seta $p v^{\prime \prime}, p v^{\prime}$, and $p l "$ subequal, setae $u^{\prime}$ the shortest on the segment, setae $p l$ " barbed, solenidion $\omega 4$ finger-shaped. Tibia: with setae $v$ " longer than $l$ ', setae $d$ and $v^{\prime}$ subequal and shorter than $l$ ', setae $v^{\prime \prime}$ barbed, solenidion $\phi 2$ finger-shaped. Genu: setae $l$ " longer than $l$ ' and setae $l$ ' longer than $v^{\prime}$, setae $l^{\prime \prime}$ barbed. Femur: with seta $d$ longer than $l^{\prime}$ and setae $l$ ' longer than $v$ ". Trochanter: with seta $v^{\prime}$.

Leg III (Figure 10a). Tarsus: with setae $p v^{\prime \prime}, t c^{\prime}$, and $t c^{\prime \prime}$ subequal and longer than setae $p l$ " and $p v^{\prime}$, setae $u^{\prime}$ the shortest on the segment, setae $p v^{\prime}$ barbed. Tibia: setae $l$ ' longer than $d$ and setae $d$ longer than $v^{\prime}$ and $v^{\prime \prime}$, solenidion $\phi 1$ small. Genu: with seta $l$ ' and $v$ 'subequal. Femur: divided into basifemur and telofemur, setae $d$ and $v^{\prime}$ inserted on telofemur, setae $v^{\prime}$ barbed and longer than $d$. Trochanter: with seta $v^{\prime}$.
Leg IV (Figure 10b). Tarsus: seta $t c$ ' thick and longer than other setae of this segment, setae $u^{\prime}$ and $p l$ " barbed. Tibia: setae $d$ barbed and longer than $v^{\prime}$, setae $l^{\prime}$ and $v^{\prime \prime}$ subequal and shorter than $v^{\prime}$, solenidion $\phi 1$ small. Genu: seta $v^{\prime}$ as long as tibial seta $v^{\prime \prime}$. Femur: divided into basifemur and telofemur, setae $d$ and $v^{\prime}$ inserted on telofemur, setae $d$ longer than $v^{\prime}$. Trochanter with seta $v^{\prime}$.

Remarks Two of the closest genera to the Neomicrodispus are Punicodoxa Mahunka and Vietodispus Mahunka; however, original descriptions of these genera are incomplete, particularly their leg chaetotaxy. We tried to access the holotypes for redescription, but unfortunately, the holotype of Punicodoxa was not available in the Hungarian Natural History Museum. Redescription of Vietodispus based on its holotype, only one microscopic slide (Figure 11), is provided above. Redescription of the genus Vietodispus revealed that this genus is very close to the genus Premicrodispus Cross. Significant similarities are as follows: one pair of cheliceral setae, same pharyngeal 


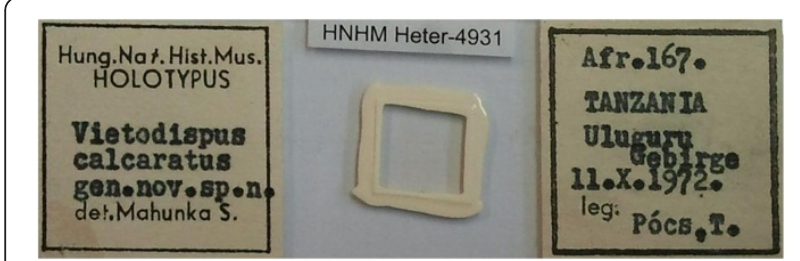

Figure 11 Microscopic slide (holotype) of Vietodispus calcaratus.

structure, absence of setae $4 a$, tibiotarsus I with 15 setae (seta $s$ absent), and posterior margin of poststernal plate tripartite. Some mentioned or other traits are variable in Premicrodispus. They are the presence or absence of the second pair of cheliceral setae, presence or absence of setae $4 a$, having two or three pairs of $p s$ setae, and having three or four solenidia on tibiotarsus I. The only distinct differences between these two genera are shapes of stigmata and cupuli (see Table 1). Therefore, it appears that Vietodispus could be considered as another subgenus of Premicrodispus.

\section{Results and discussion}

Neomicrodispus gen. nov. has some apomorphic character states which are as follows (see Table 1): tibiotarsus I with 14 setae and three solenidia, no seta $4 a$, one pair of cheliceral setae, posterior margin of posterior sternal plate entire, reduced pharyngeal pumps I and III, and three setae on tibia IV. In contrast, the new genus has the following plesiomorphies: three pairs of pseudoanal setae and rounded cupuli. It should be noted that the presence of three setae on tibia IV $\left(d, l^{\prime}\right.$, and $\left.v^{\prime}\right)$ may be a reduction and could be as a result of homoplasy, as it is also found in Reductodispus Mahunka, 1977, but it is otherwise unique in Microdispidae. However, the loss of a tibial seta ( $v$ " absent) is found in several scutacarid genera and in the pygmephorid Elattoma ( $l$ 'absent), one of the most derivative genera of the family Pygmephoridae (Khaustov 2006; Rahiminejad et al. 2011a).

Due to the apparently shared apomorphies (synapomorphies) of the following characters, the new genus is presumably closely related to the genera MicrodispusParamicrodispus-Punicodoxa: posterior margin of posterior

Table 2 List of microdispid mites associated with arthropods

\begin{tabular}{|c|c|c|}
\hline Mite species & Arthropod host & Reference(s) \\
\hline Glyphidomastax rettenmeyeri Cross 1965 & $\begin{array}{l}\text { Neivamyrmex opacithorax (Emery), N. nigrescens } \\
\text { (Cresson) (Hymenoptera: Formicidae) }\end{array}$ & Cross (1965) \\
\hline Myrmecodispus spp. & Ants (Hymenoptera: Formicidae) & Cross (1965) \\
\hline Peponocara cathistes Cross, 1965 & Arenivaga apacha (Saussure) (Blattodea: Corydiidae) & Cross (1965) \\
\hline Perperipes ornithocephala Cross, 1965 & $\begin{array}{l}\text { Eciton burchelli (Westwood), E. hamatum (Fabricius), Nomamyrmex } \\
\text { esenbecki (Westwood) (Hymenoptera: Formicidae) }\end{array}$ & Cross (1965) \\
\hline Premicrodispus chandleri (Cross, 1965) & Nomamyrmex hartigi (Westwood) (Hymenoptera: Formicidae) & Cross (1965) \\
\hline Premicrodispus silvestris (Jacot, 1936) & Reticulitermes flavipes (Kollar) (Isoptera: Rhinotermitidae) & Cross (1965) \\
\hline Unguidispus spp. & Ants (Hymenoptera: Formicidae) or their nests & Mahunka (1970); Kurosa (1979) \\
\hline Reductodispus rettenmeyerorum Mahunka, 1977 & Labidus praedator (Smith, 1858) (Hymenoptera: Formicidae) & Mahunka (1977a) \\
\hline Caesarodispus spp. & Ants (Hymenoptera: Formicidae) & $\begin{array}{l}\text { Mahunka (1977b); Khaustov } \\
\text { (2009b); Loghmani et al. (2014a) }\end{array}$ \\
\hline Premicrodispus scolopendrae Rack, 1979 & Scolopendra morsitans L. (Chilopoda: Scolopendridae) & Rack (1979) \\
\hline Microdispus hastatus Mahunka, 1981 & Ant nest & Mahunka (1981) \\
\hline Paramicrodispus crenulatus (Sevastianov, 1978) & $\begin{array}{l}\text { Pterostichus niger (Schaller) (Coleoptera: Carabidae); } \\
\text { Lucanus ibericus Motschulsky (Coleoptera Lucanidae) }\end{array}$ & $\begin{array}{l}\text { Khaustov (2009a); Hajiqanbar } \\
\text { et al. (2012) }\end{array}$ \\
\hline Premicrodispus brevisetus Khaustov, 2006 & Oxythyrea cinctella (Schaum) (Coleoptera: Scarabaeidae) & Rahiminejad et al. (2010) \\
\hline $\begin{array}{l}\text { Paramicrodispus scarabidophilus Hajiqanbar } \\
\text { and Rahiminejad, } 2012\end{array}$ & Oryctes nasicornis L. (Coleoptera: Scarabaeidae) & Hajiqanbar et al. (2012) \\
\hline $\begin{array}{l}\text { Premicrodispus akermanae (Sevastianov } \\
\text { and Chydyrov, 1988) }\end{array}$ & Oryctes nasicornis L. (Coleoptera: Scarabaeidae) & Hosseininaveh et al. (2013) \\
\hline Premicrodispus krczali Khaustov, 2006 & Oxythyrea cinctella (Schaum) (Coleoptera: Scarabaeidae) & Loghmani et al. (2014b) \\
\hline $\begin{array}{l}\text { Premicrodispus paramaevi Hosseininaveh } \\
\text { and Hajiqanbar, } 2014\end{array}$ & Lucanus ibericus Motschulsky (Coleoptera: Lucanidae) & Hosseininaveh et al. (2014) \\
\hline $\begin{array}{l}\text { Premicrodispus spinosus Hosseininaveh } \\
\text { and Hajiqanbar, } 2014\end{array}$ & $\begin{array}{l}\text { Corticeus unicolor Piller and Mitterpacher } \\
\text { (Coleoptera: Tenebrionidae) }\end{array}$ & Hosseininaveh et al. (2014) \\
\hline $\begin{array}{l}\text { Neomicrodispus iranicus Hajiqanbar and } \\
\text { Hosseininaveh, gen. nov., sp. nov. }\end{array}$ & Oryctes nasicornis L. (Coleoptera: Scarabaeidae) & This study \\
\hline
\end{tabular}


sternal plate entire and three solenidia on tibiotarsus I. However, the new genus differs from the above genera by apomorphies absence of setae $4 a$ and three setae on tibia IV (setae $4 a$ present and tibia IV with four setae in the genera Microdispus, Paramicrodispus, and Punicodoxa). The provisional synapomorphic character states absence of setae $4 a$ and three solenidia on tibiotarsus I could imply that the new genus is close to the genus Vietodispus but it differs from Vietodispus by apomorphies posterior margin of posterior sternal plate entire, 14 setae on tibiotarsus I, and 3 setae in tibia IV (posterior margin of posterior sternal plate tripartite, tibiotarsus I with 15 setae and tibia IV with 4 setae in the genus Vietodispus). Totally, it seems the new genus probably places near the genus Paramicrodispus based on these potential synapomorphies: gnathosomal capsule two times longer than wide, one pair of cheliceral setae, reduced pharyngeal pumps I, posterior margin of posterior sternal plate entire, tibiotarsus I with 14 setae and three solenidia. Nevertheless, the new genus differs from the genus Paramicrodispus by the apomorphies no seta $4 a$, three setae on tibia IV, and reduced pharyngeal pumps III (seta $4 a$ present, four setae on tibia IV, and larger pharyngeal pumps III in the genus Paramicrodispus).

According to Table 2, about 35\% of described taxa of the family Microdispidae have some kind of relationship with arthropods. Except for Premicrodispus scolopendrae Rack, 1979 which has been found on a centipede, other arthropod-associated microdispids are associated with insects, mostly ants (Hymenoptera: Formicidae) and beetles (Coleoptera). It appears these mites feed on fungi particles available in habitats of their hosts (see Navarro et al. 2010). Many ant nests are suitable and rich sources of various kinds of fungi (Hölldobler and Wilson 1990). Regarding the coleopterans hosts, they usually utilize woody debris, rotten wood, and decaying stumps in the forests. Such habitats include a vast variety of fungi (Grove 2002) that microdispids could exploit in a similar way to that observed in many adult female fungivorous heterostigmatic mites, e.g., Dolichocybidae (Rahiminejad et al. 2011a; Katlav et al. 2014), Scutacaridae (Jagersbacher-Baumann and Ebermann 2013), Neopygmephoridae (Hajiqanbar and Khaustov 2013), and Pygmephoridae (Rahiminejad et al. 2011b; Hofstetter and Moser 2014).

\section{Conclusions}

Taking into account the new genus described in this paper, the Microdispidae now comprises 18 genera. Further examination of the nests of social insects and insects dwelling in decaying woods, where fungi are abundant, should reveal more undescribed microdispid mites. A review of arthropod associations showed that these mites are primarily associated with ants and beetles, where a rich source of various kinds of fungi particles is easily obtained.
Competing interests

The authors declare that they have no competing interests.

\section{Authors' contributions}

FH prepared the line drawings, performed the measurements, and prepared the early version of the descriptive parts of the manuscript. $\mathrm{HH}$ conceived the study, examined the type series of the new genus and species and lent material, discussed the taxonomic parts, and completed the manuscript. Both authors read and approved the final manuscript.

\section{Acknowledgements}

We express our sincere thanks to Vahid Rahiminejad for collecting the material. We also appreciate Dr. László Dányi of the Hungarian Natural History Museum for the loan of the holotype of Vietodispus calcaratus Mahunka, 1975 and Dr. Alexandr Khaustov (Tyumen State University, Russia) for the critical review of the manuscript. This research was financially supported by Tarbiat Modares University, which is greatly appreciated.

Received: 19 May 2014 Accepted: 22 August 2014

Published: 6 September 2014

\section{References}

Cross EA (1965) The generic relationships of the family Pyemotidae (Acarina: Trombidiformes). Univ Kansas Sci Bull 45:29-275

Grove SJ (2002) Saproxylic insect ecology and the sustainable management of forests. Annu Rev Ecol Syst 33:1-23

Hajiqanbar H, Khaustov AA (2013) New species and record of the genus Petalomium (Acari: Heterostigmatina: Neopygmephoridae) associated with ants (Hymenoptera: Formicoidea) from Iran. Biologia 68:712-719

Hajiqanbar H, Rahiminejad V, Fathipour Y (2012) New insect host records for mites of the family Microdispidae (Acari: Heterostigmata), with description of a new species of the genus Paramicrodispus. Entomol Sci 15:309-313

Hofstetter RW, Moser JC (2014) The role of mites in insect-fungus associations. Annu Rev Entomol 59:537-557

Hölldobler B, Wilson EO (1990) The ants. Belknap, Cambridge

Hosseininaveh F, Hajiqanbar H, Talebi AA (2013) First record of the Premicrodispus akermanae (Sevastianov \& Al Douri, 1988) (Acari: Microdispidae) from Iran. In: Joharchi O, Saboori A (eds) Abstract book of 2nd international Persian congress of acarology. Karaj, p 15

Hosseininaveh F, Hajiqanbar H, Talebi AA (2014) Two new species of the genus Premicrodispus (Acari: Microdispidae) associated with beetles (Coleoptera: Lucanidae, Tenebrionidae), with a key to Palaearctic species of the genus. J Nat Hist doi:10.1080/00222933.2014.953225

Jagersbacher-Baumann J, Ebermann E (2013) Methods for rearing scutacarid mites (Acari, Heterostigmatina) and the influence of laboratory cultures on morphometric variables. Exp Appl Acarol 59:447-462

Kaliszewski M, Athias-Binche F, Lindquist EE (1995) Parasitism and parasitoidism in Tarsonemina (Acari: Heterostigmata) and evolutionary considerations. Adv Parasitol 35:335-367

Katlav A, Hajiqanbar H, Talebi AA (2014) First record of the genus Acanthomastix Mahunka, 1972 (Acari: Dolichocybidae) from Asia, with the description of a new species. Internat J Acarol 40:7-14

Khaustov AA (2006) A review of the genera Premicrodispus Cross, 1965 and Dolichodispus gen. nov. (Acari: Microdispidae) of Crimea. Acarina 14:155-174

Khaustov AA (2008) Mites of the family Scutacaridae of Eastern Palaearctic. Akademperiodyka, Kiev

Khaustov AA (2009a) A new genus and three new species of the mite family Microdispidae (Acari: Heterostigmata) from Crimea. Acarina 17:65-73

Khaustov AA (2009b) New and little known species of mites of the genus Caesarodispus (Acari, Heterostigmata, Microdispidae) associated with ants (Hymenoptera, Formicidae) from Ukraine. Vestn Zool 43:388-393

Kurosa K (1979) Three new species of Unguidispus (Acari, Heterostigmata, Microdispidae) from Japan. Annot Zool Jap 521:63-71

Lindquist EE (1986) The world genera of Tarsonemidae (Acari: Heterostigmata): a morphological, phylogenetic and systematic revision, with a reclassification of family-group taxa in Heterostigmata. Mem Entomol Soc Can 136:1-517

Loghmani A, Hajiqanbar H, Talebi AA (2014a) New species and new record of the genus Caesarodispus (Acari: Heterostigmatina: Microdispidae) phoretic on Temnothorax sp. (Hymenoptera: Formicidae) with a key to world species of the genus. Ann Zool 64:273-278 
Loghmani A, Hajiqanbar H, Talebi AA (2014b) New records of mites of the superfamily Pygmephoroidea (Acari: Heterostigmatina) associated with insects from northeastern Iran and new host records. Syst Appl Acarol 19:154-159

Mahunka S (1970) Considerations on the systematics of the Tarsonemina and the description of new European taxa (Acari: Trombidiformes). Acta Zool Hung 16:137-174

Mahunka S (1975) Athiopische Tarsonemiden (Acari: Tarsonemidae), I. Acta Zool Acad Sci Hung 21:369-410

Mahunka S (1977a) The examination of myrmecophilous mites based on the investigations of Dr. C. W. Rettenmeyer (Acari). I. Acta Zool Acad Sci Hung 23:99-132

Mahunka S (1977b) Neue und interessante Milben aus dem Genfer Museum XIX. Einige Angaben zur Kenntnis der Milbenfauna der Ameise-Nester (Acari: Acarida, Tarsonemida). Arch Sci 30:91-106

Mahunka S (1978) Beitrage zur kenntnie der Tarsonemiden-fauna (Acari: Tarsonemida) Tunesiens. Parasitol Hung 11:113-125

Mahunka S (1981) The Pygmephoroid fauna of the Hortobágy National Park (Acari: Tarsonemida). Fauna Horto Nat Park 1:343-370

Navarro M, Gea F, Escudero-Colomar L (2010) Abundance and distribution of Microdispus lambi (Acari: Microdispidae) in Spanish mushroom crops. Exp Appl Acarol 50:309-316

Rack G (1979) Brennandania scolopendrae sp. n. von Scolopendra morsitans L. (Acarina, Tarsonemida, Pygmephoroidea, Microdispidae). Rev Zool Afr 93:376-381

Rahiminejad V, Hajiqanbar H, Fathipour Y (2010) First record of phoresy of Microdispidae (Acari: Prostigmata) on Scarabaeidae (Insecta: Coleoptera). In: Manzari S (ed) Proceedings of 19th Iranian plant protection congress. Tehran, p 352

Rahiminejad V, Hajiqanbar H, Fathipour Y (2011a) Redefinition of the Genus Dolichocybe (Acari: Dolichocybidae), with description of two new species associated with insects. Ann Entomol Soc Amer 104:627-635

Rahiminejad V, Hajiqanbar H, Fathipour Y (2011b) Two new species of the genus Elattoma (Acari: Heterostigmatina: Pygmephoridae) phoretic on Morimus verecundus (Coleoptera: Cerambycidae) from Iran. Zootaxa 2903:48-56

Walter DE, Lindquist EE, Smith IM, Cook DR, Krantz GW (2009) Order Trombidiformes. In: Krantz GW, Walter DE (eds) A manual of acarology, 3rd edn. Texas Tech University Press, Lubbock

doi:10.1186/s40555-014-0058-7

Cite this article as: Hajiqanbar and Hosseininaveh: A new genus and species of the family Microdispidae (Acari: Prostigmata) associated with Oryctes nasicornis (Coleoptera: Scarabaeidae) and redescription of the monotypic genus Vietodispus Mahunka, 1975. Zoological Studies 2014 53:58.

\section{Submit your manuscript to a SpringerOpen ${ }^{\circ}$ journal and benefit from:}

- Convenient online submission

- Rigorous peer review

- Immediate publication on acceptance

- Open access: articles freely available online

- High visibility within the field

- Retaining the copyright to your article

Submit your next manuscript at $>$ springeropen.com 